\title{
ON THE OHLIN LEMMA FOR HERMITE-HADAMARD-FEJÉR TYPE INEQUALITIES
}

\author{
TERESA RAJBA
}

Abstract. Using Ohlin's Lemma [21] on convex stochastic ordering, we get a simple proof of known Hermite-Hadamard-Fejér type inequalities. We also prove new inequalities. Using $s$ convex stochastic ordering [12], we also give some Hermite-Hadamard-Fejér type inequalities in the case of higher order convex functions. The obtained results are useful in proving some inequalities between the quadrature operators [31], [32].

Mathematics subject classification (2010): 26A51, 26D15, 60E15, 41A55.

Keywords and phrases: Hermite-Hadamard-Fejér type inequality, higher order convexity, convex stochastic ordering, quadrature rules.

\section{REFERENCES}

[1] M. BessenYeI, Hermite-Hadamard-type inequalities for generalized convex functions, J. Inequal. Pure Appl. Math. 9 (2008), 1-51.

[2] M. Bessenyei AND Zs. PÁles, Higher-order generalizations of Hadamard's inequality, Publ. Math. Debrecen 61, 3-4 (2002), 623-643.

[3] M. Bessenyei AND Zs. PÁles, Hadamard-type inequalities for generalized convex functions, Math. Inequal. Appl. 6, 3 (2003), 379-392.

[4] M. BESSENYEI AND Zs. PÁLES, On generalized higher-order convexity and Hermite-Hadamardtype inequalities, Acta Sci. Math. (Szeged) 70, 1-2 (2004), 13-24. MR 2005e:26012.

[5] M. BESSENYEI AND Zs. PÁLES, Characterization of higher-order monotonicity via integral inequalities, Proc. R. Soc. Edinburgh Sect. A 140A, 1 (2010), 723-736.

[6] H. BRASS AND K. PETRAS, Quadrature theory. The theory of numerical integration on a compact interval, Mathematical Surveys and Monographs, 178. American Mathematical Society, Providence, RI, 2011.

[7] H. BRASS AND G. SCHMEISSER, Error estimates for interpolatory quadrature formulae, Numer. Math. 37, 3 (1981), 371-386.

[8] P. Bullen, A criterion for n-convexity, Pacific J. Math. 36, 1 (1971), 81-98.

[9] J.L. BRENNER AND H. Alzer, Integral inequalities for concave functions with applications to special functions, Proc. Roy. Soc. Edinburgh Sect. A 118 (1991), 173-192.

[10] P. CZINDER, A weighted Hermite-Hadamard-type inequality for convex-concave symmetric functions, Publ. Math. Debrecen 68, 1-2 (2006), 215-224. MR 2006m:26044.

[11] P. CZINDER AND Zs. PÁLES, An extension of the Hermite-Hadamard inequality and an application for Gini and Stolarsky means, J. Inequal. Pure Appl. Math. 5 (2004), no. 2, Article 42, pp. 8 (electronic). MR 2005d:26020.

[12] M. DenUit, C.LefEVRE AND M. ShAKED, The s-convex orders among real random variables, with applications, Math. Inequal. Appl. 1 (1998), 585-613.

[13] S. S. Dragomir, C. E. M. Pearce, Selected Topics on Hermite-Hadamard Inequalities and Applications, RGMIA Monographs, Victoria University, (2000),

(online: http://rgmia.vu.edu.au/monographs/).

[14] L. FejÉR, Über die Fourierreihen, II, Math. Naturwiss. Anz. Ungar. Akad. Wiss. 24 (1906), 369-390.

[15] A.M. FInK, A best possible Hadamard inequality, Math. Inequal. Appl. 2 (1998), 223-230. 
[16] A. Gilányi And Zs. PÁLes, On convex functions of higher order, Math. Inequal. Appl. 11, 2 (2008), 271-282.

[17] M. Klaričić BAKUla, J. PeČARIĆ AND J. Perić, Extensions of Hermite-Hadamard inequality with applications, Math. Inequal. Appl. 15, 4 (2012), 899-921.

[18] M. KUCZMA, An Introduction to the Theory of Functional Equations and Inequalities, Prace Naukowe Uniwersytetu Śląskiego w Katowicach, vol. 489, Państwowe Wydawnictwo Naukowe - Uniwersytet Śląski, Warszawa, Kraków, Katowice, 1985.

[19] A. LuPAS, A generalisation of Hadamard's inequality for convex functions, Univ. Beograd. Publ. Elek. Fak. Ser. Mat. Fiz., no. 544-576, (1976), 115-121.

[20] D. S. Mitrinović AND I. B. Lacković, Hermite and convexity, Aequationes Math. 28, 3 (1985), 229-232.

[21] J. OHLIN, On a class of measures of dispersion with application to optimal reinsurance, ASTIN Bulletin 5 (1969), 249-266.

[22] J. E. PeČarić, F. Proschan And Y. L. Tong, Convex functions, Academic Press Inc., 1992.

[23] A. Pinkus AND D. WulBert, Extending $n$-convex functions, Studia Math. 171, 2 (2005), 125-152.

[24] T. Popoviciu, Sur quelques proprietes des fonctions d'une ou de deux variables reelles, Mathematica 8 (1934), 1-85.

[25] T. Popoviciu, Les Fonctions Convexes, Hermann, Paris, 1944.

[26] T. RAJBA, New integral representations of nth order convex functions, J. Math. Anal. Appl. 379 (2011), 736-747.

[27] A. Ralston, A First Course in Numerical Analysis, McGraw-Hill Book Company, New York, St. Louis, San Francisco, Toronto, London, Sydney, 1965.

[28] W. Roberts and D. E. Varberg, Convex Functions, Pure and Applied Mathematics, vol. 57, Academic Press, New York-London, 1973.

[29] P.M. VASIĆ AND I.B. LACKOVIĆ, Some complements to the paper: On an inequality for convex functions, Univ. Beograd Publ. Elek. Fak., Ser. Mat. Fiz., no. 544-576 (1976), 59-62.

[30] Sz. W A̧SOWICZ, Support-type properties of convex functions of higher order and Hadamard-type inequalities, J. Math. Anal. Appl. 332, 2 (2007), 1229-1241.

[31] Sz. W A̧SOWICZ, Inequalities between the quadrature operators and error bounds of quadrature rules, J. Inequal. Pure Appl. Math. 8, 2 (2007), Article 42, 8 pp.

[32] Sz. W A̧SOWICZ, On quadrature rules, inequalities and error bounds, J. Inequal. Pure Appl. Math. 9, 2 (2008), Article 36, 4 pp.

[33] Sz. WA̧SOwICZ, A new proof of some inequality connected with quadratures, J. Inequal. Pure Appl. Math. 9, 1 (2008), Article 7, 3 pp.

[34] Sz. WAssowicz, On some extremalities in the approximate integration, Math. Inequal. Appl. 13 (2010), 165-174.

[35] E. W. Weisstein, Chebyshev Quadrature, From MathWorld - A Wolfram Web Resource, (online: http://mathworld.wolfram.com/ChebyshevQuadrature.html.

[36] E. W. Weisstein, Legendre-Gauss Quadrature, From MathWorld - A Wolfram Web Resource, (online: http://mathworld.wolfram.com/Legendre-GaussQuadrature.html.

[37] E. W. Weisstein, Lobatto Quadrature, From MathWorld - A Wolfram Web Resource, (online: http://mathworld.wolfram.com/LobattoQuadrature.html.

[38] E. W. Weisstein, Simpson's Rule, From MathWorld - A Wolfram Web Resource, (online: http://mathworld.wolfram.com/SimpsonsRule.html. 